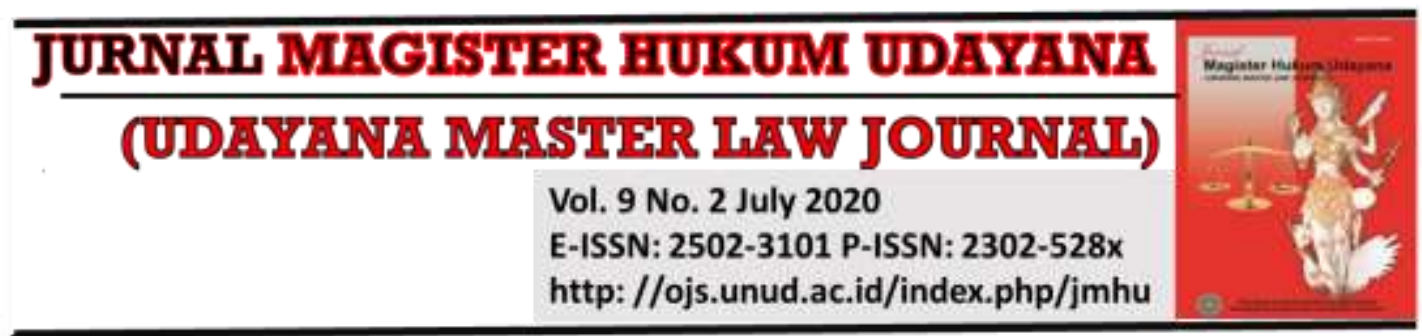

\title{
Health Issues in The WTO Dispute Concerning Importation of Chicken Meat and Products between Indonesia and Brazil
}

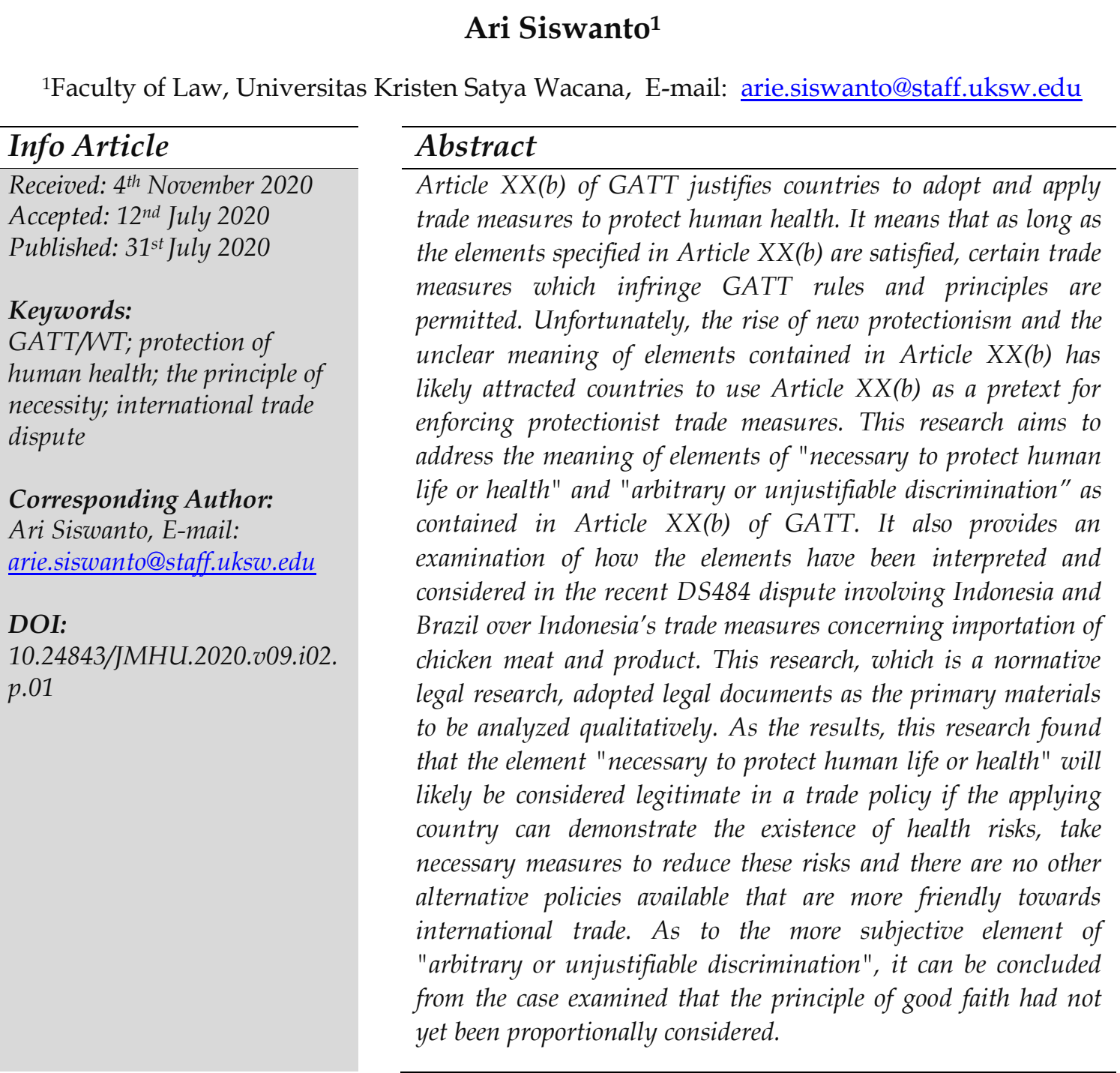

\section{Introduction}

Although the efforts to establish an international organization to deal with international trade issues have been initiated since the end of World War II through discussions in Bretton Woods, United States, this idea was only realized about five decades later with the formation of the World Trade Organization (WTO). Therefore, in the period between the 1940s and early 1990s, there was no specific and comprehensive international organization to regulate global international trade. However, apart from the absence of such international organization, before the formation of the WTO countries had concluded the General Agreement on Tariffs and 
Trade (GATT) in 1947, which since then has served as a normative framework for international trade in goods.

In the beginning, GATT was intended to be a temporary agreement (interim agreement) that was applied by trading states while waiting for the formation of a particular international organization dealing with international trade among countries. However, in reality, GATT has become a long-term international agreement, even beyond the time of the formation of the WTO. ${ }^{1}$

The formation of the WTO as an international trading system organization in 1994 did not put GATT to an end. When the WTO was finally formed, GATT has become the main international agreement that must be accepted by every WTO member. To differentiate from pre-WTO GATT (which is often also referred to as "GATT 1947"), GATT that applies after the formation of WTO is often mentioned as "GATT 1994". Even so, from the legal point of view, basically, GATT 1947 and GATT 1994 are two different international treaties. GATT 1994 has a wider scope since it includes GATT 1947 and other legal instruments agreed in the GATT context before 1 January 1995. ${ }^{2}$

As a legal framework, GATT contains principles and provisions to encourage free international trade. Therefore, the principles and provisions of GATT reflect the preference for removing trade barriers and minimizing government intervention and prohibiting discrimination in international trade to ensure that each country has equal access to global markets. ${ }^{3}$

Careful examination of the provisions in the GATT will reveal that the basic contractual obligations that bind each GATT party are quite clear. Countries are bound by the obligation to provide non-discriminatory treatment to fellow parties, to uphold the tariff commitments set out in the schedule of concessions, to remove non-tariff barriers and to provide domestic market access for foreign products. The parties are also prohibited to apply discriminatory treatment to imported products in such a way as to benefit domestic over imported products.

Nevertheless, GATT itself also contains exclusion provisions that provide possibilities for GATT countries to take action that deviates from obligations under GATT in certain situations. One of the articles in GATT that contains exceptions and is the focus of this article is Article XX (b) which stipulates that as long as certain trade measures are not applied in such a way that constitutes a means of arbitrary or unjustifiable discrimination between trading partners with a similar condition, or a disguised restriction on international trade, the GATT shall not be interpreted as preventing the adoption or enforcement of measures necessary to protect life or health of human, animal or plant.

The above-mentioned article indicates that GATT has not been intended to prevent countries from taking actions necessary to protect the lives and health of humans, animals or plants. In other words, it is possible for any country to take actions that

\footnotetext{
${ }^{1}$ Van den Bossche, P. (2017). The Law and Policy of the World Trade Organization - Text, Cases and Materials, $4^{\text {th }}$ ed. Cambridge: University Press., p. 81

2 Matsushita, M., Schoenbaum, T. J., Mavroidis, P. C., \& Hahn, M. (2015). The World Trade Organization - Law, Practice and Policy, $3^{\text {rd }}$ ed. Oxford: Oxford University Press., p. 11.

${ }^{3}$ Lowenfeld, Andreas F. (2008). International Economic Law, Oxford: Oxford University Press., pp. 30-31.
} 
deviate from the obligations of GATT, as long as those actions are carried out to protect the lives and health of humans, animals or plants, and are carried out in accordance with the requirements indicated in the chapeau of Article XX, i.e. (a) the act is not an arbitrary action or illegally discriminates against other countries under the same conditions (arbitrary and unjustifiable discrimination), and (b) the act is not a disguised restriction on international trade.

In reality, sometimes for various reasons such as protection of the domestic market and local industries, countries try to avoid certain obligations imposed by GATT. Therefore, it is not uncommon for countries to refer to Article XX of GATT as a justification for avoiding their duties under international trade law. The rise of protectionism in the last decade has been identified by Choi (2017) who emphasizes that since the global economic crisis of 2008, protectionist measures such as import restriction and tariff increase have risen substantially. ${ }^{4}$

When a country decides not to carry out obligations arising from the norms of international trade in GATT (for example by giving different less favorable treatment to imported products), it is always possible that the action will bring harm to other trading partners. Referring to Article XX of GATT, such actions that (potentially) bring disadvantage to other trading partners can only be justified if they fulfill the conditions specified in Article XX of GATT. Otherwise, the avoidance of that obligation will simply constitute a violation of the provisions of GATT and expose that country to the possibility of facing claims from the injured countries. Therefore, Article XX of GATT, including the letter (b) which is the focus of this paper, is an important touchstone to determine whether the avoidance of GATT obligations by a country can be justified or not. Unfortunately, a dispute situation will quickly arise when one country avoids GATT obligations under the pretext of Article $X X$, but other (potentially) disadvantaged countries hold the different view that the conditions specified in Article XX are not fulfilled and thus a violation of GATT provisions takes place.

There is always a chance that the formulation of rules in international agreements, including GATT, contains weaknesses, for example, due to poor drafting. Concerning this issue, Jeutner explicitly argues that imperfect drafting can lead to a dilemma in which a legal instrument contains inherently contradictory norms and cannot thus respond to actual events properly. ${ }^{5}$

One weakness that often arises in legal instruments is the unclear meaning of rules coupled with ambiguity. This weakness can exist because after all the rules in legal instruments are expressed through the formulation of sentences that sometimes cannot accommodate the complete and appropriate underlying normative ideas. If this happens, an ambiguous condition arises in which a sentence becomes open to more than one interpretation of meaning. This issue was precisely raised by Solan, who emphasizes that

[w] use language to communicate, but our language faculties are imperfect communication systems. We misspeak; we think we heard someone say one thing when the speaker actually said

\footnotetext{
${ }^{4}$ Choi, N. (2017). Did Anti-dumping Duties Really Restrict Import? : Empirical Evidence from the US, the EU, China, and India, East Asian Economic Review, 21 (1), 3-27. http://dx.doi.org/10.11644/KIEP.EAER.2017.21.1.321., p.3.

5 Jeutner, V. (2017). Irresolvable Norm Conflicts in International Law - The Concept of a Legal Dilemma, Oxford: Oxford University Press., pp. 45-46.
} 
another; we use words that have broader or narrower applications than we wish; ... we produce ambiguous utterances that can mean one thing or another, which we can sometimes resolve from context, but at other times we cannot; and we use terms that are vague and can be understood in ways that are closely related, but conceptually distinct. ${ }^{6}$

Following Solan's view, the difference in the meaning of an ambiguous sentence will possibly develop into a more serious dispute. Likewise, the ambiguity of the sentences contained in Article XX(b) of GATT can lead to international trade disputes between countries. $^{7}$

One dispute concerning Article XX (b) took place between Indonesia and Brazil which had been decided by the WTO Dispute Settlement Body (DSB) in 2017. In this dispute, which will also be referred to as "DS484 dispute", Brazil questioned trade policy adopted by Indonesia on chicken meat and chicken products imported from abroad. Indonesia, among others, used GATT Article XX (b) as a justification. However, the arguments developed based on this article failed to convince the DSB Panel to approve Indonesia's actions. In the end, in this trade dispute, Indonesia suffered defeat and had to revise its policies which were considered as violating GATT obligations. ${ }^{8}$

Considering the broad, multi-interpretative and ambiguous formulation of Article XX, an appropriate and predictable interpretation is required. This paper is intended to explore how the pre-WTO and WTO Panels give meaning to the elements "necessary to protect human life or health" contained in GATT Article XX (b). The choice of the elements in letter (b) of Article XX of GATT is motivated by the fact that until now there has not been a definitive crystallization of the concept of what is meant by "protection of life or human health" in an international trade context. The condition makes the reason for health protection can be misused by countries to protect domestic producers of certain products. ${ }^{9}$ This possibility is also noticed by Bettcher et al., when they found that the health significances of global agreements in trade must be understood, and correct facts should be achieved so that public health is not used "naively" for other political ends, such as justifying unwarranted economic protectionism. ${ }^{10}$ On the other hand, it is also true that international trade may collide with public interests or social priorities of developing economies. ${ }^{11}$ In such a case, a country needs to consider whether it will prioritize compliance with international trade agreements, or achieving its national interests.

${ }^{6}$ Solan, L.M. (2016). "Why is it so Difficult to Resolve Vagueness in Legal Interpretation" in Keil G. \& Poscher, R. (eds.), Vagueness and Law - Philosophical and Legal Perspectives. Oxford: Oxford University Press., p. 231.

${ }^{7}$ Delany, L., Signal, L. \& Thomson, G. (2018). International trade and investment law: a new framework for public health and the common good. BMC Public Health, 18 (1), 1-12. doi: https://doi.org/10.1186/s12889-018-5486-6., p.2.

8 Indonesia - Measures Concerning the Importation of Chicken Meat and Chicken Products, WT/DS484/R, Panel Report, 17 October 2017, para. 8.3.

${ }^{9}$ Epps, T. (2008). International Trade and Health Protection - A Critical Assessment of the WTO's SPS Agreement. Cheltenham: Edward Elgar Publishing., p. 105.

${ }^{10}$ Bettcher, D.W., Yach, D. \& Guindon, G. E. (2000). Global Trade and Health: Key Linkages and Future Challenges, Bulletin of the World Health Organization, 78, 521-534., p. 530.

${ }^{11}$ Aliaj, K. \& Mekaj, G. (2018). Legal Aspects of International Trade, ILIRIA International Review, 8(2)., p.184. 
In addition to examining the conceptual aspects of Article XX (b) of GATT, a clearer meaning of these elements is expected to be obtained by analyzing an in concreto case. The case that will thoroughly be examined is the previously mentioned DS484 dispute, which is interesting considering that it is the most recent case concerning Article XX (b) of GATT which has been resolved by the WTO DSB Panel. To bring about an in-depth discussion, this study is aimed at achieving the following purpose:

1. to understand the meaning of "necessary to protect human life or health" as an element contained in GATT Article XX (b).

2. to understand the meaning of "arbitrary or unjustifiable discrimination" element that is contained in the chapeau of Article XX of GATT.

3. to analize how the elements of "necessary to protect human life or health" and "arbitrary or unjustifiable discrimination" are interpreted and considered in the DS484 dispute involving Indonesia and Brazil.

\section{Research Method}

Considering that this research is focused on efforts to clarify ambiguous norms contained particularly in GATT Article XX(b), normative legal research method was used appropriately. To obtain a comprehensive picture of the problems studied, this study utilizes a statutory approach, conceptual approach as well as an analytical approach. Documentary studies are used to explore relevant legal materials, which in this case include sources of international law, --especially legal instruments within the framework of the WTO--, national regulations claimed to be violating international legal obligations, as well as documents and reports from GATT and WTO panels relating to relevant cases, especially DS484 cases. The legal materials used in this study are grouped into two main categories, which are the primary and secondary legal materials. The primary legal materials consist of international treaties concluded within the framework of GATT and WTO and also authoritative national legal sources in the form of national regulations and laws. The secondary legal materials refer to monographs, books, journal articles as well as previous research reports on the related research topic. The relevant legal materials, both the primary and secondary ones, were gathered through a documentary study by using conventional library access and electronic library sources. Upon acquiring the required information, qualitative analysis was then used based on the research problems that have been previously formulated.

\section{Results and Discussion}

Based on the problems stated above, following general description of the background of the case, the results and discussion of this paper will be divided into three parts. The first part discusses the meaning of the element "necessary to protect human life or health" as contained in GATT Article XX (b). After that, the discussion will be focused on the element of "arbitrary or unjustifiable discrimination" mentioned in the chapeau of Article XX of GATT. The last part of this discussion will describe how these two elements are interpreted and taken into consideration by the WTO DSB Panel examining the DS484 dispute between Indonesia and Brazil. 
It is important to note that this dispute emerged in a time when protectionist policy increased among countries. The desire of the countries to support the competitiveness of their producers has, in turn, actualized a problem of aggravation of trade relations between the countries.12 As Choi noted, since the 2008 economic crisis, protectionist measures have risen significantly. ${ }^{13}$ Economic instability has accordingly generated the desire of states to resort to protectionist measures to stabilize national economies. ${ }^{14}$ However, as in DS484 case being studied, the national interest to guarantee food safety may also encourage countries to adopt certain standards. Unfortunately, up to this time, there are no international rules precisely controlling the use of food safety standards. ${ }^{15}$ In such a condition, the vagueness and less inadequate dissemination of standards among countries have raised concerns of a new tendency of protectionism, disguised under the cloak of trade regulations on product health and safety standards. ${ }^{16}$

Referring to Ethier's works (2013), as far as concerning import measures, this protectionist initiatives may be implemented in the form of import embargo/prohibitions, minimum import price requirements, import authorization requirements, health and safety restrictions, labeling/ marketing/ packaging requirements, and so on. ${ }^{17}$ Saldarriaga (2017) also mentions another requirement that may pose protectionist nature, termed "the Process and Production Methods (PPMs)" requirement by which an importing country imposes a certain environmental standard for the production of goods in exporting countries. ${ }^{18}$ As in the DS484 case being examined, some trade disputes with environmental aspects are also related to exemptions stipulated in GATT Article XX.

\subsection{The meaning of "necessary to protect human life or health" element}

Referring to Article XX (b) of GATT, one of the conditions that must be fulfilled for trade policy to be exempted from the provisions of GATT is that the policy is necessarily taken by the country concerned to protect human safety or health. Because the term is rather general, the term "necessary" may give rise to ambiguity, for example

12 Gordeeva, T. A. M. A. R. A. (2013), International Trade Disputes in Modern Regulatory Paradigm, International Economic Policy, 2, 96-118., p. 96

${ }^{13}$ See Choi (2017), note 3, supra.

14 Panchenko, V. \& Reznikova, N. (2017). From Protectionism to Neo-Protectionism: New Dimensions of Liberal Regulation, International Economic Policy, (2), 91 -111., p. 91.

${ }^{15}$ Saraithong, W. (2018). Trade Restriction Rationale for Food Safety Implementation: Evidence from Southeast Asian Countries, Cogent Economics \& Finance, 6(1), 1553278. https://doi.org/10.1080/23322039.2018.1553278., p.2.

${ }^{16}$ Ferraz, L.P. do C., Ribeiro, M. \& Monasterio, P. (2017). On the Effects of NonTariff Measures on Brazilian Exports, Revista Brasileira de Economia, 71(3), 301-320. doi: DOI 10.5935/00347140.20170014., p.302.

${ }^{17}$ Ethier, W.J. (2013). The Trade-Agreement Embarrassment, Journal of East Asian Economic Integration, 17(3), 243-260. doi: http://dx.doi.org/10.11644/KIEP.JEAI.2013.17.3.265., pp.254255.

${ }^{18}$ Calle Saldarriaga, M.A. (2018), Sustainable Production and Trade Discrimination: An Analysis of the WTO Jurisprudence, ACDI, 11, 221. doi: dx.doi.org/10.12804/revistas.urosario.edu.co/acdi/a.6543., pp.224-225. 
about what criteria should be applied to determine that policy needs to be taken and who should provide an assessment of these conditions.

The significance of the "necessary" element in GATT Article XX (b) has elaborated in several disputes. In the 1988 Canada - Herring \& Salmon dispute, ${ }^{19}$ the WTO DSB Panel provided a view that the word "necessary" has an essential correlation with the policy objectives to be achieved. For example, if a country thinks that certain policy measures that run against the provisions of GATT need to be taken to protect its natural resources, the measures must be so essential to be able to realize the protection of natural resources as the policy objectives. In other words, even if a measure has the potential to protect natural resources, it must still have a certain weight that must be met by the action concerned, namely the necessity to take the measure to protect natural resources. ${ }^{20}$

A similar idea can also be found in the 2017 DS484 dispute, in which the DSB Panel is of the opinion that the import measures are taken by Indonesia, which basically violated the provisions of GATT can only be justified under Article XX (b) of GATT if there is a nexus between the actions taken and the objectives of human health protection. More explicitly, because the policy objective to be achieved is the protection of human health, the Panel believes that such action must have the capability of reducing health risks to humans. ${ }^{21}$ However, going forward one step ahead of the opinion in the case of Canada - Herring \& Salmon (1998), in the DS484 dispute, the WTO DSB Panel elaborates the term "necessary" by presenting four criteria to examine whether a policy that excludes GATT provisions can qualify as "necessary". This examination is called the "necessity test" which consists of four factors, namely (1) the importance of the objectives, (2) the contribution of the measure to that objective, (3) the trade-restrictiveness of the measure, and then (4) a comparison between the challenged measure and possible less trade-restrictive alternatives should then be carried out. 22

The first factor is intended to measure the weight of importance of the objectives to be achieved through a policy that by nature violates the provisions of GATT. The second factor is closely related to the capability of the policy intended to realize the objectives to be achieved. The third factor is intended to measure the negative nature of the policy taken, namely the impact of the policy on international trade. Meanwhile, the fourth factor is held to ensure that the policy is taken because there are no other alternative actions that may bring a less negative impact on international trade.

A similar measure to construct the meaning of the word "necessary" in Article XX of GATT can also be found in the DSB decision in the case of the European Community Asbestos (2000)23 which also refers to DSB considerations in the case of United States Gasoline (1996). In these cases, the word "necessary" is understood in the context of Article XX (d) instead of Article XX (b) which regulates the importance of health

${ }^{19}$ Canada - Measures Affecting Exports of Unprocessed Herring and Salmon, L/6268 - 35S/98, 22 March 1988.

20 United States - Restrictions on Imports of Tuna, Report of the Panel DS29/R, 16 June 1994, para. 5.36

${ }^{21}$ Indonesia - Measures, , WT/DS484/R, 17 October 2017, para. 7.220.

22 Indonesia - Measures, , WT/DS484/R, 17 October 2017, para. 7.224.

${ }^{23}$ European Communities - Measures Affecting Asbestos and Asbestos - Containing Products, WT/DS135/R, 18 September 2000 
protection. Article XX (d) regulates the importance of ensuring the implementation of national laws and regulations in such a way so that it does not violate GATT provisions. Just like Article XX (b), Article XX (d) of GATT also contains the "necessary" element. Although intended for different purposes, the word "necessary" found both in Article XX (b) and Article XX (d) is considered similar. ${ }^{24}$

Citing the Panel's opinion in the case of United States - Gasoline (1996), the Panel in the case of European Community - Asbestos (2000) asserts that a contracting party of the GATT cannot justify a measure inconsistent with another GATT provision as 'necessary' in terms of Article XX(d) if an alternative measure which is not inconsistent with other GATT provisions is available to it. Additionally, in cases where a measure consistent with other GATT provisions is not reasonably available, a contracting party is obliged to use the measures which entail the least level of inconsistency with other GATT provisions." 25

From the opinion reflected in the two cases, it seems quite clear that the Panel requires that in order to be excluded from GATT provisions based on Article XX's "necessary" element, any measure taken must be a measure without alternatives to realize the objectives to be achieved. Thus, based on what might be properly called the "alternative measure test", an act of excluding GATT provisions based on Article XX is not considered to fulfill the "necessary" element if in addition to these actions there are other alternative actions that can be taken. This principle was also confirmed earlier in the case of Thailand - Cigarettes (1990). In other words, the measure must be an "ultimatum remedium" (a final resort) which must indeed be taken to realize the objectives justified in Article XX of GATT.

With regard to the element of "protect human life or health", there is a principle in resolving WTO disputes that this element may justify trade measures based on the provisions of Article XX of GATT if a country could demonstrate the existence of life or human health risks being faced as well as the background of the adoption of such measures, which in ordinary situation constitute a breach of GATT provisions. In addition to evidence of human health risks, an element that must also be present to justifiably exclude trade measures from GATT provisions based on Article XX (b) is the presence of a relationship between the measures taken on one side and the goal of achieving and keeping human health on the other side. ${ }^{26}$

With regards to the element of "protect human life or health", it is worth noting that in the decisions of disputes examined by the WTO GATT / DSB panels, this element was never considered in depth. The Panel tends to briefly examine the evidence presented by the disputing parties, which is mainly presented in the form of reports of scientific studies. This raises a problem because it is quite possible that the results of scientific studies submitted by the parties to the dispute are in conflict with each other. This is one of the reasons that hypothetically cause almost all exceptions under Article XX (b) are always deemed ineligible.

The author maintains that if the WTO Panel provides proportional space for analysis of elements of human life or health, maybe the issue of human health has not just become a peripheral issue that is always subordinate to the issue of international trade.

24 Thailand - Restrictions on Importation of and Internal Taxes on Cigarettes, DS10/R-37S/200, 7 November 1990, para. 74.

${ }^{25}$ European Communities - Measures, WT/DS135/R, 18 September 2000, para. 3.478.

${ }^{26}$ Indonesia - Measures, WT/DS484/R, 17 Oktober 2017, para. 7.20. 
Interpretation of this element will not actually be obstructed by obstacles since the concepts of human health and human life standards have been well elaborated through various international organizations dealing with the health sector, especially WHO.

So far, various studies on the relationship between international trade and aspects of human health appear to be more dominated by the issue of intellectual property rights related to the production of internationally traded medicines, including issues concerning the compulsory license in pharmaceutical products involving trade between developing and developed countries. ${ }^{27}$ Some researchers also try to explore the relationship between human rights (including the right to life and security) and international trade, which surprisingly less significant. ${ }^{28}$ However, apparently a wider spectrum of health issues are increasingly gaining attention in regional trade agreements. ${ }^{29}$ Within the WTO system itself, specific norms to deal with health issues and international trade in agricultural products have also developed through the adoption of the Sanitary and Phytosanitary Agreement. ${ }^{30}$

\subsection{The meaning of "arbitrary or unjustifiable discrimination" element}

In some disputes, the phrase "arbitrary or unjustifiable discrimination" is linked to the principle of "similar measure for a similar reason" ("equal treatment, for the same reason"). This means that the condition of "arbitrary or unjustifiable discrimination" does not exist when a country applies the same treatment to other countries with the same conditions and for the same reasons. This principle can be seen in the United States - Prohibition of Imports of Tuna and Tuna Products from Canada case (1982). The case began when on August 31, 1979, The United States imposed a ban on tuna imports from other countries. Before the adoption of the measure, a US fishing vessel was seized by Canadian authorities in waters that have been disputed by the United States and Canada. Canada then alleged that the United States implemented the import ban policy discriminatively against Canada. The panel established by GATT in the case asserted that the United States' actions against Canada were not discriminatory, because similar actions had also been taken against other tuna exporting countries. On that basis, the Panel, in this case, argued that the actions of the United States do not necessarily represent "arbitrary or unjustifiable discrimination."31

A similar understanding of "similar measure for similar reason" principle as stated above can also be seen in another case, namely the case of Canada - Measures Affecting

${ }^{27}$ Wartini, S. (2018). The Legal Implication of Compulsory Licence Pharmaceutical Products in the TRIPS Agreement to the Protection of the Right to Health in Developing Countries, Jurnal Dinamika Hukum, 8(1). 1-11., p.2.

28 See for example, Yang, J. (2013). The Effect of International Trade on Rule of Law, Journal of East Asian Economic Integration, 17(1), 27-53. doi: http://dx.doi.org/10.11644/KIEP.JEAI.2013.17.1.258., p. 49.

${ }^{29}$ Labonté, R. (2019). "Trade, Investment and Public Health: Compiling The Evidence, Assembling The Arguments", Globalization and Health, (15)1, https://doi.org/10.1186/s12992018-0425-y. p.2.

${ }^{30}$ Hoekman, B. (2018). 'Behind-the-Border' Regulatory Policies and Trade Agreements, East Asian Economic Review, 22(3), 243-273. doi:http://dx.doi.org/10.11644/KIEP.EAER.2018.22.3.344., p.257.

31 United States - Prohibition of Imports of Tuna and Tuna Products from Canada, L/5198-29S/91, 22 Februari 1982, para. 4.8 . 
Exports of Unprocessed Herring and Salmon (1988). In this case, Canada's prohibition of the export of unprocessed herring and salmon is questioned by the United States, one of the importing countries for Canada's unprocessed herring and salmon. Canada states that the policy is implemented based on the principle of most-favored nations, and thus there is no discrimination "between countries with similar conditions" .32

A more elaborated discussion about the meaning of arbitrariness or unjustifiability of discrimination is found in the United States - Gasoline case (1996) and The United States - Shrimps (1998). WTO Appellate Body in The United States - Shrimps (1998) maintained that a measure will have the characteristic of 'arbitrary or unjustifiable discrimination between countries where the same conditions prevail', if three elements exist. First, the application of the measure must result in discrimination. Second, discrimination must be arbitrary or unjustifiable. Third, this discrimination must occur between countries where the same conditions are present. ${ }^{33}$

Other relevant cases to understand the meaning of Article XX of GATT are the 2004 United States - Gambling Case (DS285) and the 2014 European Community - Seal Products Cases (DS400 and DS401). The United States - Gambling Case began when the state of Antigua \& Barbuda objected to the policies adopted by the United States relating to cross-border gambling services. In that case, the United States' measure that prohibits the provision of cross-border gambling services and related restrictions imposed on international money transfers and payments is considered to violate the GATS (General Agreement on Trade in Services) by Antigua \& Barbuda. Meanwhile, the United States, among others, stated that the measures taken were permissible based on Article XIV of GATS. Although it is more concerned with the issue of trade in services, this case is relevant to understand the chapeau part of Article XX of GATT since the same elements, namely "arbitrary or unjustifiable discrimination" and "disguised restriction on trade" are mentioned both in the chapeau of Article XX of GATT and Article XIV of the GATS. On that basis, the Panel in the United States Gambling Case also refers to the interpretation that appears in several previous disputes which were related to Article XX of GATT.

In the United States - Gambling case the WTO panel confirmed that the chapeau of Article XX GATT (and Article XIV GATS) was intended to prevent abuse of the provisions concerning exceptions. Regarding the "arbitrary or unjustifiable discrimination" element, the Panel reiterated the view that arose in the 1998 United States - Shrimps case that an action or policy would be deemed to meet this element if it fulfilled three conditions. Firstly, these actions or policies must bring about discrimination. Secondly, discrimination has to be arbitrary or unjustified. Thirdly, discrimination arises between countries with the same conditions. Regarding the "disguised restriction" element, the panel is of the opinion that this element must be seen jointly with the element of "arbitrary or unjustifiable discrimination" and, -referring to the case of US-Gasoline--, the panel also holds the opinion that the meaning of "disguised" is not only limited to conditions where a discriminatory policy is not publicly announced.

The European Community (EC) - Seal Products cases started when Canada and Norway raised objections to the rules and policies for trade in seal products

32 Canada - Measures, L/6268 - 35S/98, 22 Maret 1988, para. 3.25.

33 United States - Shrimps, WT/DS58/AB/R6, 6 November 1998, para. 150. 
implemented by the European Union through Regulation (EC) Number 1007/2009 and Regulation (EU) Number 737/2010. Based on the regulations, products originating from seals can only be sold in the European Union market if they meet certain standards, including the requirements that those products should be derived from seals captured by the Inuit people or other indigenous communities (termed "IC hunt") or from seals captured in the framework of marine resource management (termed "MRM hunt").

Both Canada and Norway claim that the EC regulations are a form of technical barriers to trade (especially for seals) and cannot be exempted by Article XX of GATT. On the contrary, the European Union believes that the rules and policies are allowed based on Article XX. In this dispute the panel also applies the same analytical step, which is grounded in the presence or absence of discrimination from the rules in question. Having analyzed the case thoroughly, the panel considered that the discriminative element was fulfilled. Furthermore, the panel also links the elements contained in the umbrella phrase of Article XX of GATT with the Agreement on Technical Barriers to Trade (TBT Agreement) which is deemed relevant to this dispute. ${ }^{34}$

According to the panel, the EC regulations related to IC hunt can basically be justified. However, since the rules are applied unfairly, they do not meet the requirements contained in the umbrella phrase of Article XX of GATT. Meanwhile, with regards to MRM hunt, the panel is of the opinion that these regulations cannot be justified and are not reasonably related to the objectives to be achieved.

Later on, the Appellate Body affirmed what is meant by the "unjustifiable" element in the GATT's Article XX umbrella phrase. Referring to the case of United States Shrimps and Brazil - Retreaded Tires, the appellate authority of the DSB stated that efforts to understand the "arbitrary" or "unjustifiable" element needs to consider whether discrimination arising from international trade measures is convincingly related to the intended purpose achieved through the application of the measures. It is at this point that the Appellate Body corrects the view of the panel which previously argued that policy discrimination against seals for commercial purposes and IC hunt was not based on rational links between rules and objectives, while on the other hand the panel paradoxically concluded that the rules could be justified. ${ }^{35}$

From the opinion of the examining as well as the appellate panel in the cases above, it can be concluded that a measure will be considered as having the character of "arbitrarily or unjustifiably discriminating between countries where the same conditions prevail" if the following three requirements are fulfilled:

a) The action must be discriminatory

b) The discriminatory action must be arbitrary or cannot be justified

c) The action discriminates countries with the same conditions

${ }^{34}$ European Communities - Measures, WT/DS400/R \& WT/DS401/R, Panel Report, 25 November 2013, para. 7.649.

${ }^{35}$ European Communities - Measures, WT/DS400/R \& WT/DS401/R, Panel Report, 25 November 2013, para. 7.650, European Communities - Measures Prohibiting the Importation and Marketing of Seal Products, WT/DS400/AB/R \& WT/DS401/AB/R, Appellate Body Report, 22 Mei 2014, para. 6.1.d. 
Nonetheless, efforts to elaborate the meaning of the phrase have by far not yet produced clarity. As to the term "discriminatory", different interpretations may present, for instance concerning whether discriminatory measure necessarily originated from different measures. Or, whether the same measures applied by one state to its trading partners necessarily constitute discriminatory measures. What is also less clear is the 'justification' requirement. This word is so subjective that different states will likely have different understanding of this word, particularly when it comes to the application of controversial trade policy. Lastly, people may also question the criteria to establish the 'same condition' requirement to which discrimination may occur.

In the same case, another general standard related to the substance of Article XX GATT can be found, namely the reasonableness standard. In the opinion of Appellate Body in the United States - Shrimps case, the chapeau of Article XX has been developed based on the principle that exceptions granted by Article XX must not be misused, so that the justifiable exceptions based on the article must be applied properly.

With regards to the term 'discrimination' found in the phrase 'arbitrary or unjustifiable discrimination between countries where the same conditions prevail', the Appellate Body in the case of United States - Gasoline also introduced another test tool called the 'foreseeability test'. According to this tool, the 'discrimination' that is relevant to Article $\mathrm{XX}$ of GATT is not unavoidable, but rather a discrimination that can be predicted in advance.36 Thus, implicitly, the Appellate Body in this case holds the view that unavoidable discriminatory conditions cannot be considered "arbitrary or unjustifiable."

In the panel's opinion in some cases, it is clear that the interpretation of element "arbitrary (discrimination)" has almost always been placed in the perspective of "arbitrary or unjustifiable discrimination" as a single phrase. This relationship is marked by the conjunction "or". Interpretation of the element of "arbitrary (discrimination)" combined with the element of "unjustifiable discrimination" may obscure the particular meaning of the two elements, because both of them tend to be considered as one part. From the legal perspective, the conjunction "or" that connects these two elements is very important. The alternative nature of the phrase carries the consequence that even if only one element is fulfilled, whether it is "arbitrary discrimination" or "unjustifiable discrimination", an exemption from GATT provisions is not justified. Therefore, it would be more appropriate if the two elements were interpreted separately, rather than considered as a single unit. Unfortunately, in the cases studied, there was no attempt to elaborate on the terms "arbitrary discrimination" and "unjustifiable discrimination" separately.

Referring to Black's Law Dictionary, "arbitrary" means "founded on prejudice or preference rather than on reason or fact." 37 The lexical definition of "arbitrary" put forward by Black later became a fairly authoritative reference, because it was held by UNCTAD (United Nations Conference on Trade and Development). In the legal context of foreign investment, UNCTAD stated that in its ordinary meaning, 'arbitrary'

${ }^{36}$ United States - Standards for Reformulated and Conventional Gasoline, WT/DS2/AB/R, 29 April 1996, p. 29.

${ }^{37}$ Garner, B. A (2009). Black's Law Dictionary, 9th edition. St. Paul MN: Thomson Reuters., p.119. 
means 'derived from mere opinion', 'capricious', unrestrained', 'despotic'. Thus, arbitral conduct has been described as 'founded on prejudice or preference rather than on reason or fact'. Arbitrariness in decision-making has to do with the motivations and objectives behind the conduct concerned. A measure that inflicts damage without serving any legitimate purpose and without a rational explanation, but that instead rests on prejudice or bias, would be categorized as arbitrary. ${ }^{38}$

Based on the meaning, it would be more appropriate if the term "arbitrary" in Article XX GATT is interpreted by examining whether or not "reason" or "fact" relating to the measures in question exists. It is implied in the Panel's opinion that "arbitrariness" is identical to "unreasonableness". This opinion, --for example--, is reflected in the opinion of the WTO DSB's appellate panel in the United States - Shrimps case (1998) which gave rise to the "Reasonableness Test" instrument.

As to the term "unjustifiable discrimination", it is crucial to underline that Article XX GATT prohibits discrimination qualified as "unjustifiable." Based on a contrario interpretation, it follows that "justifiable" discrimination is not necessarily prohibited. Etymologically, the term "justifiable" has a very close meaning to the qualification of "capable of being proven just or true, morally defensible." 39 Therefore, the interpretation of the term "justifiable" should also provide space for moral considerations underlying the trade measures taken in the view of Article XX of GATT. At this point, subjective aspects of the country taking measures by using Article XX of GATT should also be considered. Consideration of the "good faith" factor will be very helpful in conditions where scientific arguments for and against a measure adopted based on Article XX of GATT are equally sound. The relevance of good faith factor in dispute settlement is heightened by the fact that good faith belongs to the category of the general principle of law. ${ }^{40}$

Because good faith is an important aspect, another type of measuring instrument needs to be introduced besides the Reasonableness Test and Foreseeability Test, which is the Good Faith Test to measure the presence (or absence) of good faith behind a measure taken within the legal framework of Article XX of GATT. Unfortunately, the good faith aspect has not yet been crystallized in a generally accepted definition. However, there is no doubt that good faith possesses characteristics as one of the general principles of law and plays an important role in all legal systems. As a general standard, good faith may be defined as honesty of purpose or sincerity of declaration ${ }^{41}$ and can be considered as an element of a subjective nature, which in the context of this paper is attached to countries that take measures under Article XX (b) of GATT.

Outside WTO, the existence and application of the principle of good faith in international interactions are common, given that this principle is classified as a general principle. In this regard, in line with the opinion of Guy Goodwin-Gill, ${ }^{42}$ countries are also bound by the principle of good faith in exercising their rights. This

\footnotetext{
${ }^{38}$ Dumberry, P. (2014). The Prohibition against Arbitrary Conduct and the Fair and Equitable Treatment Standard under NAFTA Article 1105, The Journal of World Investment \& Trade, 15 (12), 117-151. doi 10.1163/22129000-01502004., p. 121.

${ }^{39}$ https:/ / www.etymonline.com/word/justifiable, accessed on October 25, 2019.

${ }^{40}$ Harley M. D. (2006). Good Faith in WTO Dispute Settlement, Melbourne Journal of International Law, 7(2), 339., p. 342.

41 ibid, p. 340

42 ibid, p. 345.
} 
means that justification for state action is not only determined based on the legality of the action, but also the "honesty of purpose." However, this aspect has not been proportionally considered in resolving disputes concerning Article XX (b) of GATT so far.

\subsection{Consideration of the "necessary to protect human life or health" and "arbitrary or unjustifiable" elements in the DS484 dispute}

DS484 dispute involved Indonesia as the respondent and Brazil as the complainant. The case started from the objection communicated by Brazil to Indonesia related to Indonesia's importation policy applied to chicken meat and products which is considered to violate international trade rules stipulated in GATT and disadvantage Brazil. It is worth noting that Brazil has been one of the main players in chicken meat export besides the United States and the European Union (EU).43

In accordance with WTO procedures, on October 16, 2014, Brazil formally demanded negotiations with Indonesia. Consultations between the two countries were held on December 15 and 16, 2014, but no settlement was agreed. Following the unsuccessful consultation, upon Brazil's request, on December 3, 2015, a panel was established by the WTO Dispute Settlement Body to examine the dispute.

In this dispute, Brazil questioned two categories of Indonesia's trade measures applied on chicken meat and products imported from Brazil, namely the general prohibitions and specific restrictions on chicken meat imports. ${ }^{44}$ Indonesia's import ban measures which is considered harmful by Brazil is the Regulation of the Minister of Agriculture of the Republic of Indonesia No. 139/Permentan/PD.410/12/2014 concerning the Importation of Carcasses, Meat and/or Processed Products into the Territory of the Republic of Indonesia ("Permentan 139/2014") and Regulation of the Minister of Trade of the Republic of Indonesia No. 46/M-DAG/PER/8/2013 concerning Provisions on the Import and Export of Animals and Animal Products ("Permendag 46/2013"). In addition, the legislation that is considered to be related to the ban on the import of meat to Indonesia is Law No. 18 of 2012 concerning Food and Law No. 7 of 2014 concerning Trade. Meanwhile, by referring to the same laws and regulations, Brazil also stated that Indonesia imposed special restrictions on imports of chicken meat from Brazil by excluding several types of chicken products from the positive list, by permitting imports of chicken meat and products only for a particular use, by unduly delaying in granting approval for health certificates and by maintaining obstacles in the Indonesian import licensing system. Besides that, other things are also questioned by Brazil, namely the stipulation of halal product supervision and certification requirements that are more stringent for imported products than for domestic products and restrictions on transportation of imported products that are required to be transported directly from the exporting countries to Indonesian entry ports. ${ }^{45}$

\footnotetext{
${ }^{43}$ Belova, A. V., Smutka, L. \& Rosochatecká, E. (2013). World Chicken Meat Market - Its Development and Current Status, Acta Universitatis Agriculturae et Silviculturae Mendelianae Brunensis, 60 (4), 15-30., p.23.

${ }^{44}$ Indonesia - Measures, WT/DS484/R, Panel Report, 17 October 2017, para. 2.2.

${ }^{45}$ Indonesia - Measures, WT/DS484/R, Panel Report, 17 October 2017, para. 2.5. and 2.6.
} 
The issue of human health specifically arises in relation to the certain "intended use" conditions as mentioned above. The conditions for the "intended use" are contained in Article 32 paragraph (2) juncto Article 4, Article 23 and Article 30 (j) of Permentan $139 / 2014$. According to these provisions, the entry of meat into Indonesian territory must obtain permission from the Minister of Agriculture which can be issued on the recommendation of the Director of Veterinary Public Health and Postharvest Ministry of Agriculture. To obtain a recommendation, the business actor must submit an application that includes, among other things, the intended use of the meat to be imported. Furthermore, the "intended use" that can be accepted as the basis for a recommendation to obtain a non-beef meat import permit is limited in Article 32 paragraph (2). Based on this article, a recommendation can be issued if the non-beef meat to be imported is intended to be used only in hotels, restaurants, caterers, industries and modern markets. Additionally, recommendations can also be issued if the non-beef meat to be imported is intended for other special purposes, namely: (a) as a gift or grant for religious, social or disaster relief purposes; (b) used by the representatives of foreign countries / international institutions and their officials serving in Indonesia; (c) used for scientific research and development; or (d) used as a non-traded sample (for exhibition purposes) up to 200 (two hundred) kilograms. Brazil considered that these restrictions on the intended use of imported non-beef meat as trade restrictions that cause losses in Brazilian chicken meat commodities. Later, Indonesia changed this restriction and only allowed non-beef meat to be imported if it was intended to be consumed in places with cold chain facilities. However, Brazil considered that these modifications do not substantially remove trade restrictions. ${ }^{46}$

Responding to Brazil's objections on this subject, Indonesia delivered an argument developed from the provisions of Article XX (b) of GATT. The requirement for the existence of cold-chain facilities is intended to avoid the repeated thawing and freezing of meat which is believed to damage the product, increase microbial growth and endanger human health. Because it is intended to protect human health, Indonesia believes that its actions to require cold-chain facilities in the use of imported chicken meat are valid under Article XX (b) of GATT.

Following the considerations of WTO Panels in Brazil - Retreaded Tires case (2007) and also the EC - Asbestos (2000), the WTO Panel examining the DS484 dispute believes that to use human health protection reason as a justification for exempting GATT provisions according to Article XX of GATT, a country must show the existence of human health risks that encourage the adoption of measures which are allegedly contrary to GATT provisions (health risk demonstration requirements).

The Panel in DS484 dispute also shows a similar logical flow of analysis as the Panel's opinion in Brazil-Retreaded Tires case and also EC-Asbestos case. Therefore, the following elements were considered successively by the Panel: (a) the existence of health risks (health risk requirements); (b) the ability of measures taken in reducing health risks (risk-reduction capability); (c) the necessity of measures to eliminate or reduce health risks in the framework of protecting human health (necessary to secure human health) and (d) the discriminatory or non-discriminatory nature of the measures taken (arbitrary or unjustifiable discrimination).

${ }^{46}$ Indonesia - Measures, WT/DS484/R, Addendum to Panel Report, 17 October 2017, para. 22. 
In DS484 dispute, the Panel confirms that Indonesia, which is trying to use Article XX (b) of GATT to justify import measures which are considered to be in conflict with GATT by Brazil, must scientifically demonstrate the existence of a "health risk" to be responded by applying the measures in question. ${ }^{47}$ In this case, Indonesia's efforts to demonstrate the existence of this "health risk" are carried out by submitting scientific evidence and relevant standards, including several scientific articles and standards for food safety requirements from several WTO member countries which show that thawing and re-freezing frozen meat at room temperatures in open space brings risks to human health ${ }^{48}$ Having considered the evidence presented by Indonesia and Brazil, the Panel believed that Indonesia could demonstrate the presence of health risks associated with thawing frozen meat at room temperature, especially in tropical regions such as Indonesia.

However, although Indonesia has demonstrated the health risks that arise from thawing frozen meat at room temperature, it does not necessarily justify Indonesia's measure to require the use of frozen imported meat only in places that have cold chain facilities. There is another aspect that was also analyzed by the Panel, namely the ability of the measures to reduce existing health risks. ${ }^{49}$

Indonesia stated that its requirement that frozen imported meat only to be used in places that have cold chain facilities is intended to guarantee that imported chicken meat sold in the market does not pose any health risk. Thus, this measure can reduce the risk of damaging human health. On the contrary, Brazil considered that Indonesia's import measures did not correlate with the health risks presented by Indonesia. Brazil identified that the health risks posed by Indonesia arose from the thawing and refreezing of meat repeatedly so that the restrictions imposed by Indonesia were considered unable to prevent the event. Brazil considered that if re-freezing is part of the problem, re-freezing of meat will not occur in traditional markets with no cold storage facilities. ${ }^{50}$

With regard to this aspect, the Panel is of the opinion that Indonesia's measure has prevented the access of imported frozen chicken meat to traditional markets which generally are not equipped with cold storage facilities. Furthermore, according to the Panel, based on the evidence presented by both countries, it is recognized that health risks exist in the event of thawing frozen meat at room temperature, not on repeated thawing and freezing. The Panel then argued that health risks emerging from thawing frozen meat at room temperature could be prevented by Indonesian measures. Thus, from this point of view, the import measures adopted by Indonesia have the capability to reduce existing health risks. ${ }^{51}$ However, this fact does not necessarily make Indonesia's measures on imported meat justified, because there are still other standards that must be fulfilled under the provisions of Article XX (b) of GATT.

${ }^{47}$ Indonesia - Measures, WT/DS484/R, 17 October 2017, para. 7.209.

48 Indonesia - Measures, WT/DS484/R, Addendum to Panel Report, Annex B-2, 17 October 2017, para. 82.

49 Indonesia - Measures, WT/DS484/R, 17 October 2017, para. 7.266.

${ }^{50}$ Indonesia - Measures, WT/DS484/R, Addendum to Panel Report, Annex B-1, 17 October 2017, para. 131.

51 Indonesia - Measures, WT/DS484/R, 17 Oktober 2017, para. 7.22. 
According to the development of interpretation in GATT / WTO dispute settlement system, the existence of health risks that encourage the adoption of a trade measure and the capacity of the measure to reduce these risks is not sufficient to justify the application of the measure based on Article XX(b) of GATT. There is one important requirement that must be met, namely that taking the measures is indeed necessary to reduce existing health risks (necessity test).

Referring to the case law that has been developing in GATT / WTO dispute settlement, the Panel in the DS484 dispute believes that the necessity test on a trade measure must consider several criteria, namely the weight of the objectives to be achieved, the contribution of the measure to the objectives to be achieved, the nature of the measure related to aspects of trade restrictions and the presence or absence of other alternative measures that do not restrict trade. ${ }^{52}$

The four criteria mentioned above are also applied in DS484 dispute. With regard to the weight of the objectives to be achieved, the Panel agreed with Indonesia that the objectives to be achieved through Indonesia's import measures are very important, namely to protect the health of humans. As for the contribution of the measures to the objectives to be achieved, the Panel believed that basically, Indonesia's measures could reduce the risks referred to above, but the Panel also states that if the aim is to ensure that the market sell only safe chicken meat, Indonesia's policy did not contribute much. ${ }^{53}$ In relation to the third standard, namely the quality of the measures related to aspects of trade restrictions, the Panel believes that basically Indonesian policy has a trade restriction dimension, because that measure directly influenced the volume of chicken meat imports to Indonesia, particularly in the context of traditional markets. Regarding the fourth criterion, the Panel believes that Indonesia could have adopted alternative measures that do not lead to trade restrictions. Because health risks exist in the event of thawing frozen meat at room temperature, Indonesia should be able to take ownership of cold storage facilities a requirement, rather than restricting the intended use of imported chicken meat and products only in hotels, restaurants, caterers, industries, and modern markets. On that basis, the Panel then argues that Indonesia's measures failed the necessity test, and therefore not justified by Article XX (b) of GATT. Because the element of necessity as required by Article XX (b) of GATT is not fulfilled, the Panel did not specifically deliberate the element of arbitrary or unjustifiable discrimination.

From this case, it is apparent that in order to be validly exempted by Article $X X(b)$ of GATT, a trade measure must pass the necessity test. However, even if a measure has passed the necessity test, other important elements need to be assessed. Otherwise, the measure will simply be regarded as an embarrassing protectionist policy which may raise trade disputes between countries.

\section{Conclusions}

With regards to the "necessary to protect human life or health" element, a consistent principle can be found in the dispute settlement practice in the WTO. The principle requires that the element of "arbitrary or unjustifiable discrimination" contained in the Article XX (b) of GATT will only be considered if the "necessary to protect human life or health" element is fulfilled. The "protection of human life or health" element has

52 Indonesia - Measures, WT/DS484/R, 17 Oktober 2017, para. 7.224.

53 Indonesia - Measures, WT/DS484/R, 17 Oktober 2017, para. 7.226. 
never been considered thoroughly in the reports of GATT / WTO Panels relating to dispute settlement involving Article $X X(b)$ of GATT. Having considered that this element is clearly one of the justifications for the exemption of GATT provisions, the absence of proportional elaboration of this element will raise conditions where measures taken by countries based on Article XX of GATT will simply be seen as trade measures in international trade. It follows that the substantial dimensions related to human health issues in international trade will always be in a peripheral position. Although more in-depth research is needed, at least it is reasonable to assume that perhaps this is the factor that makes of the many cases in Article XX (b) only one case that really shows that the reasons for the protection of human health can be accepted as legitimate reasons for exempting GATT provisions, namely the case of EC-Asbestos (2000).

The "arbitrary or unjustifiable discrimination" element in the chapeau or umbrella phrase of Article XX of GATT tends to be interpreted as a single phrase. This approach of interpretation is actually inaccurate because the relationship between the elements "arbitrary" and "unjustifiable" in this phrase is alternative, as indicated by the use of the conjunction "or". It is the view of the author that it would be more appropriate if the term "arbitrary" and "unjustifiable discrimination" are interpreted separately.

Concerning the "necessary to protect human life or health" element as contained in Article XX (b) of GATT, the Panel in the DS484 dispute follows the interpretation of the WTO case law which emphasizes the need to consider four aspects, namely the existence of health risks as the background of taking a measure, the capability of the measure to reduce existing health risks, the necessity of taking the measures and the non-discriminatory characteristic of the measures. In DS484 dispute between Indonesia and Brazil, the element of necessity is not fulfilled in Indonesia's measures, so the "arbitrary or unjustifiable discrimination" element was not specifically considered. Because the element of necessity is not fulfilled, Indonesia's measure concerning restricted use of imported chicken meat limited only in hotels, restaurants, catering, industry, and modern markets were not justified by the provisions of Article XX (b) of GATT.

\section{References}

\section{$\underline{\text { Books }}$}

Epps, T. (2008). International Trade and Health Protection - A Critical Assessment of the WTO's SPS Agreement. Cheltenham: Edward Elgar Publishing.

Garner, B. A (2009). Black's Law Dictionary, 9th edition. St. Paul MN: Thomson Reuters. Jeutner, V. (2017). Irresolvable Norm Conflicts in International Law - The Concept of a Legal Dilemma, Oxford: Oxford University Press.

Matsushita, M., Schoenbaum, T. J., Mavroidis, P. C., \& Hahn, M. (2015). The World Trade Organization - Law, Practice and Policy, $3^{\text {rd }}$ ed. Oxford: Oxford University Press.

Solan, L.M. (2016). "Why is it so Difficult to Resolve Vagueness in Legal Interpretation" in Keil G. \& Poscher, R. (eds.), Vagueness and Law - Philosophical and Legal Perspectives. Oxford: Oxford University Press. 
Van den Bossche, P. (2017). The Law and Policy of the World Trade Organization - Text, Cases and Materials, $4^{\text {th }}$ ed. Cambridge: University Press.

\section{Journals}

Aliaj, K. \& Mekaj, G. (2018). Legal Aspects of International Trade, ILIRIA International Review, 8(2).

Belova, A. V., Smutka, L. \& Rosochatecká, E. (2013). World Chicken Meat Market - Its Development and Current Status, Acta Universitatis Agriculturae et Silviculturae Mendelianae Brunensis, 60 (4), 15-30.

Bettcher, D.W., Yach, D. \& Guindon, G. E. (2000). Global Trade and Health: Key Linkages and Future Challenges, Bulletin of the World Health Organization, 78, 521534.

Calle Saldarriaga, M.A. (2018), Sustainable Production and Trade Discrimination: An Analysis of the WTO Jurisprudence, ACDI, 11, 221. doi: dx.doi.org/10.12804/revistas.urosario.edu.co/acdi/a.6543.

Choi, N. (2017). Did Anti-dumping Duties Really Restrict Import? : Empirical Evidence from the US, the EU, China, and India, East Asian Economic Review, 21 (1), 3-27. http://dx.doi.org/10.11644/KIEP.EAER.2017.21.1.321

Delany, L., Signal, L. \& Thomson, G. (2018). International trade and investment law: a new framework for public health and the common good. BMC Public Health, 18 (1), 1-12. doi: https:// doi.org/10.1186/s12889-018-5486-6.

Dumberry, P. (2014). The Prohibition against Arbitrary Conduct and the Fair and Equitable Treatment Standard under NAFTA Article 1105, The Journal of World Investment \& Trade, 15 (1-2), 117-151. https:/ / doi.org/10.1163/22129000-01502004

Ethier, W.J. (2013). The Trade-Agreement Embarrassment, Journal of East Asian Economic Integration, 17(3), 243-260. doi: http://dx.doi.org/10.11644/KIEP.JEAI.2013.17.3.265

Ferraz, L.P. do C., Ribeiro, M. \& Monasterio, P. (2017). On the Effects of NonTariff Measures on Brazilian Exports, Revista Brasileira de Economia, 71(3), 301-320. https://doi.org/10.5935/0034-7140.20170014

Gordeeva, T. A. M. A. R. A. (2013), International Trade Disputes in Modern Regulatory Paradigm, International Economic Policy, 2, 96-118

Harley M. D. (2006). Good Faith in WTO Dispute Settlement, Melbourne Journal of International Law, 7(2), 339.

Hoekman, B. (2018). 'Behind-the-Border' Regulatory Policies and Trade Agreements, East Asian Economic Review, 22(3), 243-273. http://dx.doi.org/10.11644/KIEP.EAER.2018.22.3.344

Labonté, R. (2019). "Trade, Investment And Public Health: Compiling The Evidence, Assembling The Arguments", Globalization and Health, (15)1, https://doi.org/10.1186/s12992-018-0425-y

Lowenfeld, Andreas F. (2008). International Economic Law, Oxford: Oxford University Press.

Panchenko, V. \& Reznikova, N. (2017). From Protectionism to Neo-Protectionism: New Dimensions of Liberal Regulation, International Economic Policy, (2), 91 - 111.

Saraithong, W. (2018). Trade Restriction Rationale for Food Safety Implementation: Evidence from Southeast Asian Countries, Cogent Economics \& Finance, 6(1), 1553278. https://doi.org/10.1080/23322039.2018.1553278 
Wartini, S. (2018). The Legal Implication of Compulsory Licence Pharmaceutical Products in the TRIPS Agreement to the Protection of the Right to Health in Developing Countries, Jurnal Dinamika Hukum, 8(1). 1-11.

Yang, J. (2013). The Effect of International Trade on Rule of Law, Journal of East Asian Economic Integration, 17(1), 27-53. doi: http://dx.doi.org/10.11644/KIEP.JEAI.2013.17.1.258.

\section{WTO Cases}

Canada - Measures Affecting Exports of Unprocessed Herring and Salmon, L/6268 - 35S/98, 22 March 1988.

European Communities - Measures Affecting Asbestos and Asbestos - Containing Products, WT/DS135/R, 18 September 2000.

European Communities - Measures Prohibiting the Importation and Marketing of Seal Products, WT/DS400/R \& WT/DS401/R, Panel Report, 25 November 2013.

Indonesia - Measures Concerning the Importation of Chicken Meat and Chicken Products, WT/DS484/R, 17 October 2017.

Thailand - Restrictions on Importation of and Internal Taxes on Cigarettes, DS10/R-37S/200, 7 November 1990.

United States - Measures Affecting the Cross-Border Supply of Gambling and Betting Services, WT/DS285/R, Panel Report, 10 November 2004.

United States - Prohibition of Imports of Tuna and Tuna Products from Canada, L/519829S/91, 22 Februari 1982.

United States - Shrimps, WT/DS58/AB/R6, 6 November 1998.

United States - Restrictions on Imports of Tuna, Report of the Panel DS29/R, 16 June 1994

\section{Treaty, Law \& Regulations}

The General Agreement on Tariffs and Trade 1994

Law of the Republic of Indonesia Number 7 of 2014 concerning Trade

Law of the Republic of Indonesia Number 18 of 2012 concerning Food

Regulation of the Minister of Agriculture of the Republic of Indonesia Number 139/Permentan/PD.410/12/2014 concerning the Importation of Carcasses, Meat and/or Processed Products into the Territory of the Republic of Indonesia

Regulation of the Minister of Trade of the Republic of Indonesia Number 46/MDAG/PER/8/2013 concerning Provisions on the Import and Export of Animals and Animal Products 